\title{
Eco-Feminism in Contemporary Female Iranian Poetry
}

\author{
Narges Bagheri \\ Associate Professor of Persian Language and Literature at Valie-Asr University of Rafsanjan \\ Shahrouz Hamidi \\ Postgradute Student of Clinical Psychology at Tehran University.
}

\begin{abstract}
Today, nature, land and environment are of the important issues that everyone in his/her own position could have an important role in protecting them. Eco-feminism is a branch of feminism that communicates between ecology and feminism. Generally speaking, it can be said that Eco-feminists stesses on the three similar issues: women's relationships with nature, the relationship between domination over women and domination over nature, the role of women in solving ecological problems. One of their main arguments is that women mainly damage more from environmental pollution in comparison to men, as a result, the environment issue is mainly a gender-related issue. There is a consensus on the moral issues of environment protection, which is based on the wemen's work and social posion, among eco-femenists. But their strategies for a change are different. One of these strategies is cultural strategy and can be related to literature and poetry. This paper explores the contemporary women's poetry from this point of view. Many of contemporary Iranian poetry samples show that they are closely linked with the nature. Respecting to the nature and environmental concerns and the preservation of nature has been reflected in their poetry and this voice can help changing the thought of society.
\end{abstract}

Keywords: Eco-feminism, poetry, women, Iran

\section{Introduction}

In many myths and old beliefs of many cultures and nations, earth is female due to fertility; women also are in charge of the reproduction and child nutrition. It makes women more similar to the nature. Eco-feminism refers to the movements and philosophies that communicate between ecology and feminism. Eco-feminism communicates between ecology and feminism. The main argument of eco-feminists is that "patriarchal suppression in the name of profit and progression destroys the nature" (Ham, 2003, 133).

The concept of eco-feminism was applied for the first time in 1974 by the French Françoise d'Eaubonne (1974) in her book "Feminism or Death Le Féminismeou la Mort. Rosemary Radford Ruether (1975) in a book titled as "New Woman, New Earth, Sexist ideologies and Human Freedom", Susan Griffin (1978) in her work titled as "Woman and Nature", Caroline Merchant (1980) in her work "The Death of Nature, women and Ecology" have tried to establish links between the simoltaneus domination over women and nature on behalf of men and proposed multiple branches of Eco-feministic theory (Twine, 2001). Since the 1980s, eco-feminist groups in particular enter social activities arena to improve the conditions of women and repel environmental threats and risks simoltaneusly (Sturgeon, 1997). In the second half of the 1980s this branch entered universities as an academic discipline (Twine, 2001).

Generally speaking, we can say that "all eco-feminists stress on three similar issues: (1) women's relationships with the nature, (2) the connections between the domination over women and domination over nature, (3) the role of women in solving ecological problems" (Henshal, 2006). 
Feminists have different justifications in favor of the environment. One of their main arguments is that "women mainly damage more from environmental pollution in comparison to men, as a result, the environment issue is mainly a genderrelated issue".

Regarding the raised issues it can be said that, eco-feminism as a new theoretical branch in the field of women's studies is promising to become a tool for the relations of domination in the contemporary world (Moshirzadeh, 2006, 423).

It is important that all eco-feminists based their shared opinions on the moral issues of environment protection and social position of women, although their strategies of changing are different. Liberal Eco-feminists tend to work within the existing and governmental structures by changing laws and cultural eco-feminists critique patriarchy and emphasize the biological and symbolic relationships between women and nature. Socialist eco-feminists focus on social justice as well as on the analusis of the ways in which both patriarchy and capitalism could dominate over women and nature.

Some of the supports of this outlook think of strengthening healthier and more optimized relations between people (especially men) and environment and in addition to defending of the values and behavioral methods that are seen more in women (but not all behavior of women) than men such as pacifism, seeking tranquility, kindness and antiauthoritarianism, argued that if such female characteristics are acquired a result all of us as well as the planet Earth will have a better life (Rahmani et al, 2009).

In various proposed theories about eco-feminism, cultural issues always have been important. According to Agarval (2010) culture is one of the four major concepts that are described about the eco-feminism. Stating that men are related mostly to the culture and women to the environment, culture is considered as superior to the environment. Therefore, women and environment are dominated by men, whis are regarded as dominant over ecosystems sources. Women are related to the environment. In fact, the contribution of women and the environment devote inferior position to themselves (Agarwal, 2010).

But Plumwood (1992) proposes the culture issue in another way; in his opinion two main branches of eco-feminism are cultural and social eco-feminism that their difference relates to their outlook on the relationship between two conceptsof woman and nature. Cultural eco-feminism tends to define nature and woman in relation to each other because it believes that women, regarding their characteristics, have more specific understanding of the nature in comparison to men (Mies \& Shiva, 1993).

As you can see, in Agrawal's opinion culture is not a womanish matter but in Palm Wood's opinion, cultural eco-feminism sees woman and nature are in relation to each other. In fact, what is closer to new theoretical feminists is not to consider the arena absolutely feminine or masculine. Examining literature which are an important part of socities' culture shows that women play an important role in the culturalization, and today many stereotypes has changed.

Feminist is a perspective and ideology towards anything that exists in the social world in relation to women. So feminism is a kind of ideology rather a research methodology. So a research coul be feminist that is equipped with this worldview. It is very important regarding the Eco-feminism as a worldview, in the first place, as well as a research methodology and problem-solving, in the second.

One of the charecteristics of a feminist research is its para-disciplinarity. Feminist research does not limit itself in a particular discourse and, with an interdisciplinary nature, tries to criticize the link between various fields of science and its resulted social act which has led to criticism and exploitation of women. On the other hand a feminist research has a pragmatic nature, i.e. it not only seeks mere theorizing but also creats social changes (Reinharz, 1992). Feminist research is paradisciplinary and seeks to create social changes in relation to the status of women in society and tries to show human diversity.

This paper has been written regarding this view and, employing Eco-feminist theories, tries to reveal women's role in changing the society tought and reflects their voice by showing the environmental concerns of women poets in poems.As Grit Guard in his book "eco-feminism, women, animals and nature" regards eco-feministic theorizing as an attempt to link 
the multiple contributions in the field of environmentalism, animal rights and feminism and considers the intrinsic value of eco-feministic theory as an attempt to reflect the voices of all currents that are associated with women, feminism and the environment (Gaard, 1993).

This study and reflection, in addition to showing the concern for women and their relationship with nature, arouses the emotions and helps to preserve it with affection and respect for the environment.

\section{Examining the environment in contemporary women's poetry}

\section{2-1. Concerns for Land and Environment Destruction}

One of the features that can be searched in the poetry of women concerns the destruction of the environment and the Earth. The most prominant effects of this view can be seen in Forough Farrokhzad poetry; nn important Iranian poet. Farrokhzad wrote this poem in the 1340s Solar Hijri when Iran had faced many developments and was getting modernized. Buildings are changing, streets are paved and distancing from nature is felt:

Nobody thinks of the flowers / Nobody thinks of the fish / Nobody wants to believe that garden is dying / that garden's heart swells under the sun / that garden's mind slowly / empties from green memories (Farrokhzad, 1989, 422)

One of the most remarkable points in this poem is intellectual confrontation of the narrator's brother. A brother who looked at the world by means of a science and math viewpoint:

My brother calls the "garden" as graveyard / my brother laughs at the rebellion of the grass/ and at the corpse of the fish/ that turn ito corrupted particles under the water's ill skin / takes numbers/ my brother finds the healing of garden / in garden destruction (Farrokhzad, 1989, 425)

In this poem the narrator hates and fears war and thinks it in opposite of life, childhood and the nature:

All day / crumbling can ne heard behind the door / and explosion / all of our neighbors plant mortars and machine guns in their gardens instead of flowers (Farrokhzad, 1989, 427).

Forough Farrokhzad regards earth helpless and alone and has always defended it in her poem:

Is the earth which vibrates beneath your feet / Ionelier than you? / O friend, O brother, O full-blood/ When reach moon write the history of the massacre of flowers (Farrokhzad, 1989, 420)

The idea of the fear of the nature destruction can also be seen in the poetry of other feminist poets: I think of the last tree /smokes outs in earth's explosion/ someone sings in the next door cell:

The sun dies / and we run out of love before oil." (Ahmadi, 2010, 135)

In this poem by Khatereh Hejazy, petroleum and chemical industry are factors for the destruction of the earth.

Sometimes the poet regards the end up of nature as the destructionof herself, for example, in Gila Mosaed's poem:

My end / is this tree / which rolls into the winter blues with lethargy (Ahmadi, 2010, 265)

Fereshteh Sari shows the world in a sheet of a newspaper containing news in which vegetables are folded in and has found its way into the kitchen:

The world has been folded / in yesterday's newspaper / Africa / gets black under soot of the pot / a bunch of radish flower / covers earthquake fault / dove's seeds / collapsed on the shelling (Ahmadi, 2010, 167)

As we can see, there is no good news in the newspaper and the world's folding metaphor shows it well. 
In Khatereh Hejazy's poem the division of the roles of women and men can be seen. In this poem when men are fighting outside the home, women take care of the earth:

But we were woman / the women of those men / so with the hope of their return / alone and relying on their own thought / drove out the pigs from farms. (Ahmadi, 2010, 176)

Driving out the pigs from farms in this poem is a strong metaphor of the multi-layered concepts.

Also, women in poetry sympathize with birds and animals, such as Nahid Kabiri's sympathes with the wounded pigeon:

I do not put demulcent on the wound of a pigeon /Neither in sleep nor awaking/l slowly /feel/it gets alienated with/ its native language/Nahid Kabiri (Ahmadi, 2010, 131)

This sympathy can be seen in the poems of Forough Farrokhzad about a butterfly:

And my brain still / is full of the voice of a butterfly's horror that has been crucified her / to a pin on a notebook/. (Forough Farrokhzad, 1989, 234)

\subsection{The Close Relationship between Women and Nature}

As mentioned in the introduction, cultural eco-feminism also regards nature a feminist issue. Trees, forests and forestry are feminist issues because they have same nature with women because both have the power for fertility and are regarded as a kind of fertilizer that raise human and this idea is more borrowed from western culture in the ground of "supposing motherhood for the Earth". From the eco-feminists viewpoint, the more women depend on the nature and the closer they get to it, the better they will understand it (Enayat, 2009). This close relationship and likeness to nature is visible in many examples of female poems.

Narges Bagheri establishes a metaphorical relationship between a woman and a tree:

Once you buried me/l become a tree when you were got back / do you remember? (Bagheri, 2012, 14)

In another poem she relates the creation of woman to the rain:

No woman come from behind the Moon / whenever it rained, / the earth chest burned / and one of us (women) moaned/ we were rootless plants / whenever the wind / brings your smell / got one of you a poet (Bagheri, 2012, 119)

In Afagh Shohani's poetry woman and sea have been considered the same:

Woman in each picnic / poured the sand for fish / man sent the hook to the sea / woman filled the glass from sea water / man grante women to the sea / women was the sea / gnomons paired on each other / man went and mixed with the sea. (Ahmadi, 2010, 195)

Rira Abbasi uses a beautiful interpretation about the sugar cane:

My son / tell me when will the sugar cane become bride? (Ahmadi, 2010, 402)

Narges Bagheri also uses such an interpretation about butterflies in other way:

Look! / Why every butterfly that return from Saidabad desert / wears my mother's clothes? (Bagheri, 2012, 108)

Or Ziba Kavei who regards wheat as a fetus:

I'm waiting for a wheat germ / that next to the left ventricle / sprouted wher beats more amorous. Ziba Kaveyi (Ahmadi, 2010, 416)

The acme of the close ties between parent and child can be seen in Forough Farrokhzad poem: 
I put the unripe bunches of wheat / under my breast / and nurse

Sometimes this makes the relationship so that the women build the nature and the role of women gets legendary:

Then I laughed / and sunflower were born. (Bagheri, 2012, 31)

And the woman builds the tree on the calm field of mountains from her eyes.

Maryam Hole has been influenced by this poem and has used the purporst in another form and established a two-way relationship with nature that is the mother of the nature on the one hand and, and on the other hand is the mother of the world:

The world is my hungry child / Let feed with a breast full of milk / like the nature more/ but /Nature / is my mother. (Ahmadi, 2010, 240)

In some cases, the female poet interferes the balance between the elements of nature and establishes a relationship and sees herself in a positin who can reconcile the moon and sun, like in Rohangiz Kerachy's poem:

Drowning in the sky sea / reconcile the sun with eye, / and the moon with my hand, / I do reconciliation the moon. Rohangiz Kerachy (Ahmadi, 2010, 242).

\section{2-3. Respecting the Elements of Nature}

Sometimes the nature elements are sancified in the poetry and poet gives great respect to them. Neda Abkari writes:

Passengers in the coffeehouses of dawn / pray of water and grass (Ahmadi, 2010, 67).

In one of the poems, Forough Farrokhzad finds her hands as a safe place for nesting swallows and takes a respectful manner:

I plant my hands in the garden / I will become green / I know / I know / and the birds will lay in the hollow of my inky fingers (Farrokhzad, 1989)

In Pegah Ahmadi's poem, the woman feeds the cows with milk, while this is always the opposite and the cows feed the human with milk:

Mother feeds a piece of cow with the milk and cries (Ahmadi, 2004, 9)

\section{2-4. Coordination and social life relationship of the poet and nature}

In many contemporary poems women consider their feelings, emotions, happiness and their other living conditions dependent on the climate and environment changes. They have borrowed from nature and its elements to show their minds better. For example, in Pegah Ahmadi's poetry collection named "My Current Days Are Throat" the narrator is weeping and complaining because of social conditions and has this coordination in many of its lines:

A generation is polluted by air / a river has gone violently and a brogan (Ahmadi, 2004, 10)

Or in other poems states her life and social conditions with the elements of nature:

When I was singed, this land was full of grass / when the it become full of tree they beat it up (Ahmadi, 2004, 8)

We become fish and have no water (Ahmadi, 2004, 17)

The complaint of social conditions sometimes takes a severer protest and criticizes the form of small buildings and apartments: 
Every day, fifty meters / Commercial Property, Barbari bread and pendant museums / passes from history (Ahmadi, 2004, 25)

It also can be seen in other poems and in oreder to save the space we just mention another example of Geranaz Mousavi:

Treeless Tehran / is not enough for our youth (Mousavi, 14)

In this example we see the poet links youth depression to treelessnee of Tehran.

\section{Conclusion}

According what had reviewed the most important concern for all eco-feminists is protection of the environment, which is based on work and social status of women but they differ in their strategies.

As said before, some supporters of this idea think of stronger and optimized relations between people (especially men) and environment. They speak of close relationship between nature and women. Female poets can play a positive role in changing society's thought by means of cultural strategy and using their poems. Reviewing literature that are an important part of socities'culture shows also that women have an important role in the culturization. Reviewing the poems of contemporary women shows that with an eco-feminism approach their womanish mindset about the environment as an important issue can be examined. In these poems, the poets concern of environmental destruction, close relationship of women and nature, respecting to nature and coordination and communication between social lives and the nature that are examples to show this issue as well.

\section{References}

[1] Agarwal, B. A. (1994). Field of One's Own: Gender and Land Rights in SouthAsia; Cambridge University Press. Cambridge.

[2] Agarwal, B. Gender and Green Governance. (2010). ThePolitical Economy of Women's Presence Within and Beyond CommunityForestry ;Oxford University Press, Oxford

[3] Gaard, Greta. (1993). Ecofeminism; Women, Animals, Nature; Philadelphia: Temple University Press.

[4] Hobgood-OsterLaura (2005). Ecofeminism - Historic and International Evolution ,in Encyclopedia of Religion and Nature, Edited by Bron Taylor, London \& New York: Continuum.

[5] Mies, M. \& Shiva, V. (1993). Ecofeminism. London: The Zed Press.

[6] Reinhartz, S. (1992). Feminist Methods' in Social Research; London: Oxford University Press.

[7] Sturgeon, N. (1997). Ecofeminism Natures - Race, Gender, Feminist Theory and Political Action; London: Rutledge.

[8] Twine, Richard. T.(2001). Ecofeminisms in Process, www. ecofem. Org / journal 